\title{
Ostrich Eggshell as an Alternative Source of Calcium Ions for Biomaterials Synthesis
}

\author{
Lorena Batista Caliman ${ }^{a, d}$, Sidney Nicodemos da Silva ${ }^{b}$, Janaína Accordi Junkes ${ }^{c, *}$,
} Viviana Possamai Della Sagrillo

\author{
${ }^{a}$ Department of Metallurgical and Materials Engineering, University of São Paulo, Av. Prof. Mello \\ Moraes 2463, 05508-030, São Paulo, SP, Brazil \\ ${ }^{b}$ Department of Materials Engineering, Federal Center of Technology Education of Minas Gerais - \\ CEFET-MG, Av. Amazonas 5253, 30421-169, Belo Horizonte, MG, Brazil \\ c University Center Tiradentes - UNIT, Av. Comendador Gustavo Paiva 5014, 57038-000, Maceió, \\ AL, Brazil \\ ${ }^{d}$ Federal Institute of Espirito Santo - IFES, Av. Vitória 1729, 29040-780, Vitória, ES, Brazil
}

Received: May 12, 2016; Revised: September 19, 2016; Accepted: January 02, 2017

\begin{abstract}
Ostrich eggshells are a potentially abundant and a high purity and low cost source of calcium to produce $\beta$-Tricalcium Phosphate ( $\beta$-TCP) and Hydroxyapatite (HA), important calcium phosphates used as biomaterials. Here, we use a wet precipitation procedure to synthesize these phosphates using ostrich eggshells as a source of calcium ions. The biphasic precipitated powder, calcined at $800^{\circ} \mathrm{C}$, is a mixture of both Hydroxyapatite and $\beta$-Tricalcium Phosphate, also known as the biomaterial Biphasic Calcium Phosphate (BCP). Physico-chemical properties of the final powder product show water and $\mathrm{CO}_{3}{ }^{2-}$ groups absorbed in the particles surface, 0.1 to $100 \mu \mathrm{m}$ particles size distribution and 11.70 $\mathrm{m}^{2} / \mathrm{g}$ of specific surface area.
\end{abstract}

Keywords: Hydroxyapatite, $\beta$-TCP, biomaterials, ostrich eggshells, recycling

\section{Introduction}

Biomaterials are synthetic or natural materials used as replacement parts of a biologic system to play a certain role in contact with a living tissue. Calcium phosphates are important bioactive and bioresorbable biomaterials. A bioactive material will slowly dissolve when in contact with a living tissue, forming a layer of biological apatite before reaching the bone, and forming a direct bond to the bone. A reabsorbable material instead will dissolve and allow that a new tissue grows inside its irregularities cavities, not necessarily interacting with the bone. Dense hydroxyapatite is an example of a bioactive material while Biphasic Calcium Phosphate (a mixture of HA and $\beta$-TCP) porous scaffolds are bioresorbable materials. That is the reason why these two phosphates are the most used biomaterial in the medical field ${ }^{1}$.

Hydroxyapatite (HA) is the inorganic component of teeth and bones and is the most popular calcium phosphate ceramic for medical use due to its excellent biocompatibility, good corrosion resistance and chemical stability. It is especially in demand as a biomaterial to restore bone defects ${ }^{2}$. Although other synthetic bone substitutes have been considered, the high costs and technological challenges involved in the engineering of biomaterials are frequently prohibitive ${ }^{3}$. For this reason, HA remains the most frequent choice for bone replacement.

Wet chemical precipitation is the most commonly used procedure for HA synthesis due to its simplicity and easy

*e-mail: janajunkes@gmail.com large-scale application ${ }^{4}$. In this procedure the temperature of the liquid medium does not exceed $100^{\circ} \mathrm{C}$ leading to the precipitation of nanometric crystals, with crystallinity and $\mathrm{Ca} / \mathrm{P}$ ratio strongly dependent on preparation conditions ${ }^{5}$. The total cost and effectiveness of this method strongly depends on the use of quality raw materials that act as a source of calcium and phosphorus precursors ${ }^{4}$. One potential low cost source material is eggshell, which can be harvested after hatching with virtually no environmental impacts.

Tricalcium phosphate $\left(\mathrm{Ca}_{3}\left(\mathrm{PO}_{4}\right)_{2}\right)$ exits in two allotropic forms: $\alpha$ e $\beta$. Its $\mathrm{Ca} / \mathrm{P}$ ratio is 1.5 , slightly smaller the HA. $\beta$-TCP can not be precipitated from aqueous solutions, it is only prepared from the calcination of Ca-deficient HA or by solid state reactions ${ }^{6}$.

The physic-chemical properties of eggshells have attracted scientific interest as natural calcium sources for biodiesel production $^{7}$ and Chen et al. (2014) recently utilized ostrich eggshells to produce heterogeneous solid catalysts ${ }^{8}$. Eggshells of different bird species have similar chemical properties, being very rich in calcium carbonate $\mathrm{CaCO}_{3}$. The largest egg of any living bird is that of the ostrich (Struthio camelus), with medium weight of $1.5 \mathrm{~kg}$, a typical size of $16 \times 12 \mathrm{~cm}$ and shell thickness of $2 \mathrm{~mm}^{3,9}$ about 20-25 times bigger than a chicken egg. A good breeding group of ostriches produces eggs with a fertility rate of at least $90 \%$. During the first laying season, females lay between 10 and 30 eggs with this rate later increasing to between 40 and 70 eggs. Moreover, when kept healthy and in good conditions they can remain productive for 25-35 years?. 
Discarded eggshells are a potential environmental issue in poultry farming, since they can occupy an enormous volume and can harbor bacteria and fungi due to the high content of organic matter. The decomposition of this matter is a potential source of diseases in addition to the terrible smell it produces ${ }^{10}$. In this study it is described the production of Biphasic Calcium Phosphate from ostrich eggshells by a wet chemical procedure with the aim of producing a high quality product and reducing agricultural waste.

\section{Material and Methods}

\subsection{Precipitation}

Ostrich eggshells were washed and milled (Marconi, MA590) for 30 minutes and calcined (EDG, FI-PQ) at $800^{\circ} \mathrm{C}$ for 3 hours to decompose organic matter and calcium carbonate. The $5.6 \mathrm{~g}$ of the resulting powder was dissolved in distilled water $(150 \mathrm{~mL})$ in order to obtain a $\mathrm{Ca}(\mathrm{OH})_{2}$ suspension.

Wet chemical precipitation aiming HA synthesis occurs through a reaction between phosphate anion and calcium salts or an acid-base reaction:

$$
\begin{aligned}
& 10 \mathrm{Ca}(\mathrm{OH})_{2(a q)}+6 \mathrm{H}_{3}\left(\mathrm{PO}_{4}\right)_{2(a q)} \rightarrow \\
& \mathrm{Ca}_{10}\left(\mathrm{PO}_{4}\right)_{6}(\mathrm{OH})_{2(s)}+18 \mathrm{H}_{2} \mathrm{O}(1)
\end{aligned}
$$

The acid-base precipitation was carried out by stirring and heating $\left(40^{\circ} \mathrm{C}\right)$ the $\mathrm{Ca}(\mathrm{OH})_{2}$, suspension, while $30 \mathrm{~mL}$ of a $2 \mathrm{M}$ solution of orthophosphoric acid was added, drop by drop ( $1 \mathrm{~mL} / \mathrm{min})$. These quantities would result in a 1.67 $\mathrm{Ca} / \mathrm{P}$ ratio phosphate. The $\mathrm{pH}$ value was maintained at 10 by adding small aliquot of $\mathrm{NH}_{4} \mathrm{OH}$ solution periodically. The resulting precipitate was vigorously stirred (magnetic stirrer) and heated $\left(40^{\circ} \mathrm{C}\right)$ for 24 hours. After vacuum filtration and drying $\left(100^{\circ} \mathrm{C} / 24 \mathrm{~h}\right)$, it was calcined (EDG, FI-PQ) at $800^{\circ} \mathrm{C}$ for 3 hours.

\subsection{Characterization}

The powder (precipitate) was characterized using specific surface area (SSA) measurements B.E.T. method (Micromeritics Gemini III 2375 Surface Area Analyzer and VacPrep 061 unit) and by X-ray diffraction (Philips X'Pert $\mathrm{X}$-ray Diffractometer with $\mathrm{Cu} \mathrm{K} \alpha$ radiation, $40 \mathrm{kV}$ and $30 \mathrm{~mA}$ from 3 to $120^{\circ}$ ). The surface characteristics of the particles were determined by Fourier Transform Infrared Spectroscopy using the DRIFT accessory (Thermo-Nicolet - Magna 560 from 400 to $4000 \mathrm{~cm}^{-1}$ and $4 \mathrm{~cm}^{-1}$ resolution). Chemical composition was analyzed by Inductively Coupled Plasma - Atomic Emission Spectroscopy (ICP) (Thermo iCAP 6300 Duo), and powders images were obtained by Scanning Electron Microscope (Leica Cambridge, Stereoscan
440, Pt-Au coat). Particle size distribution was determined by a laser diffraction analyzer after ultrasound preparation (Mastersizer 2000).

\section{Results and Discussion}

The ostrich eggshells were crushed manually, then milled for 30 minutes and its composition was determined by XRD (Figure 1a). The only inorganic phase present was calcium carbonate (International Centre for Diffraction Data - ICDD, 86-2334). After calcination, the XRD (Figure 1b) analysis indicated that all the carbonate had decomposed into calcium oxide (ICDD, 37-1497). This was later dissolved in distilled water to prepare a calcium hydroxide suspension for the synthesis reaction.

a)
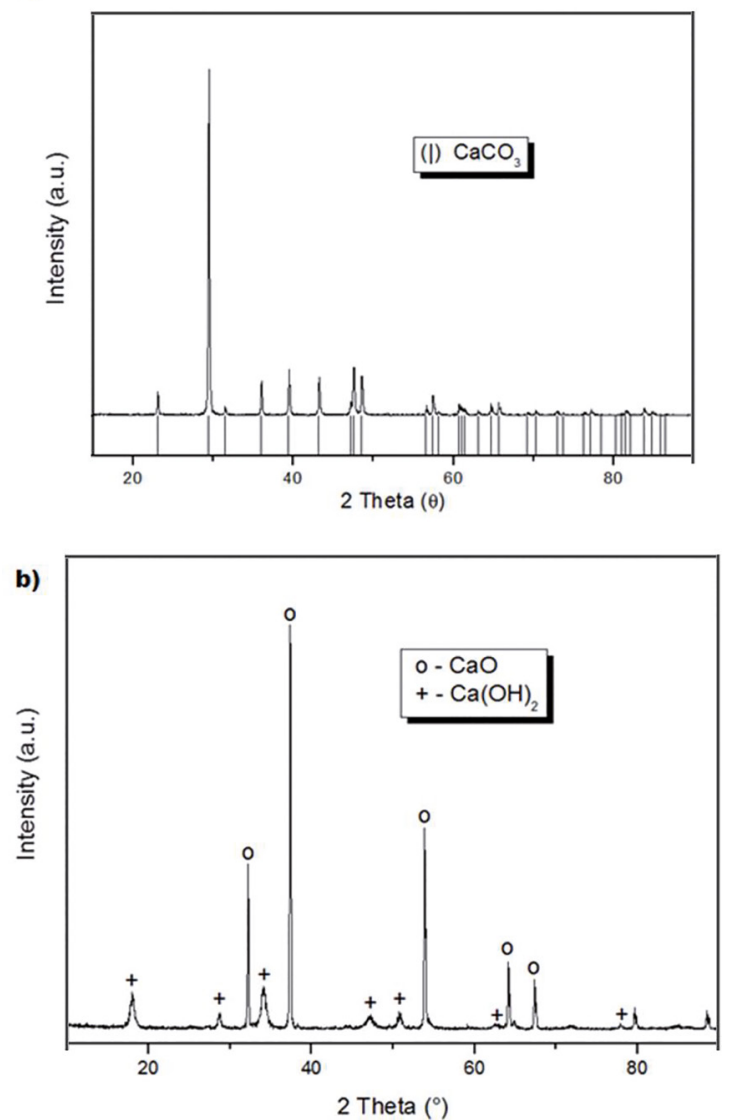

Figure 1: XRD patterns: (a) Milled ostrich eggshell and (b) calcined powder.

The dried final powder obtained by precipitation was analyzed by XRD and the patterns matched with HA (ICDD, 9-432). No other phases were observed (Figure 2a).

Nevertheless, two major differences were noticed after calcination (Figure 2b): crystallinity increase (peaks became longer and thinner), and a second phase apparition, identified 


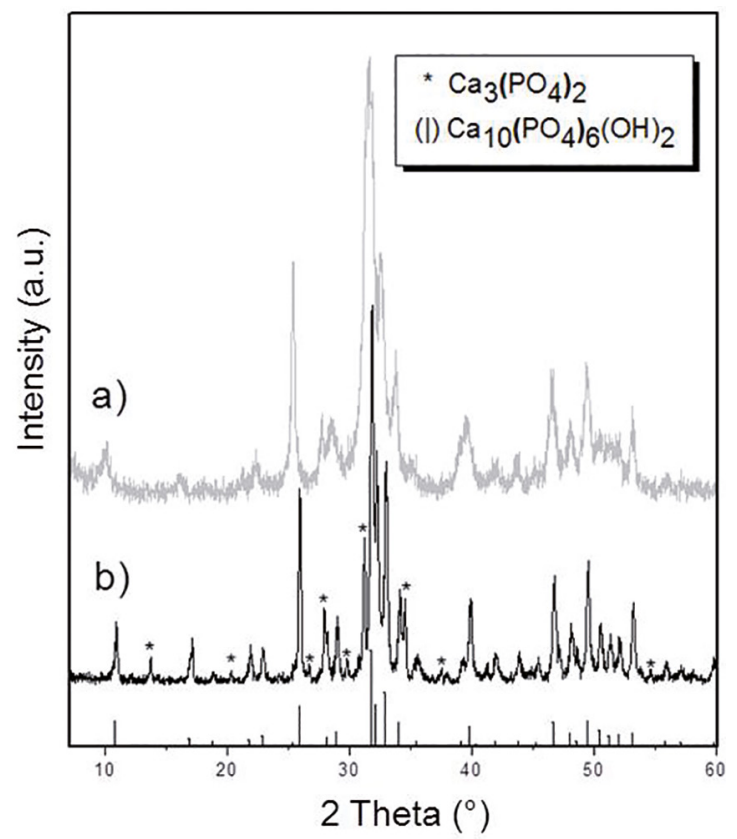

Figure 2: (a) Precipitate powder and (b) calcined powder XRD patterns.

as $\beta$-Tricalcium Phosphate - $\beta$-TCP (ICDD, 9-169). The appearance of this phase indicates that the precipitated powder was a calcium-deficient Hydroxyapatite (d-HA). Obtaining a calcium deficient $\mathrm{HA}$ is a common characteristic of the wet chemical precipitation, even in ideal conditions ${ }^{6}$.

The $\beta$-TCP appearance results from calcium-deficient HA instability above $700^{\circ} \mathrm{C}$. As previously reported ${ }^{11-13}$, d-HA (Ca/P ratio between 1.5 and 1.67$)$, when heated to temperatures higher than $700^{\circ} \mathrm{C}$, decomposes into a biphasic powder of stoichiometric HA and $\beta$-TCP. Indeed, Mortier et al. ${ }^{11}$ observed that d-HA $\left(\mathrm{Ca}_{10-x}\left(\mathrm{HPO}_{4}\right)_{x}\left(\mathrm{PO}_{4}\right)_{6-x}(\mathrm{OH})_{2-x}\right.$ $0<x<1$ ) phase transformations occur at different temperatures, as follows:

$$
\begin{gathered}
\mathrm{Ca}_{10-x}\left(\mathrm{HPO}_{4}\right)_{x}\left(\mathrm{PO}_{4}\right)_{6-x}(\mathrm{OH})_{2-x} \cdot n \mathrm{H}_{2} \mathrm{O} \\
<250^{\circ} \mathrm{C} \quad \downarrow(\mathrm{I})
\end{gathered}
$$

$$
\begin{gathered}
\mathrm{Ca}_{10-x}\left(\mathrm{HPO}_{4}\right)_{x}\left(\mathrm{PO}_{4}\right)_{6-x}(\mathrm{OH})_{2-x} \cdot\left(\mathrm{H}_{2} \mathrm{O}\right)_{x}+(n-x) \mathrm{H}_{2} \mathrm{O} \\
250-700^{\circ} \mathrm{C} \quad \downarrow(\mathrm{II}) \\
\mathrm{Ca}_{10-x}\left(\mathrm{P}_{2} \mathrm{O}_{7}\right)_{x}\left(\mathrm{PO}_{4}\right)_{6-2 x}(\mathrm{OH})_{x} \cdot x \mathrm{H}_{2} \mathrm{O} \\
700-800^{\circ} \mathrm{C} \quad \downarrow(\mathrm{III}) \\
(1-x) \mathrm{Ca}_{10}\left(\mathrm{PO}_{4}\right)_{6}(\mathrm{OH})_{2}+3 x \mathrm{Ca}_{3}\left(\mathrm{PO}_{4}\right)_{2}+x \mathrm{H}_{2} \mathrm{O}
\end{gathered}
$$

Stoichiometric HA is the major phase in the final powder. The phase proportion was determined by Rietveld refinement: HA represented $79.1 \% \mathrm{w}$ and $\beta$-TCP $20.9 \% \mathrm{w}$. As soon as it was evidenciated that precipitated HA was slightly calcium deficient, a chemical analysis was performed to determine the $\mathrm{Ca} / \mathrm{P}$ ratio (Table 1 ).
Table 1. Chemical analysis.

\begin{tabular}{lcc}
\hline & $\mathrm{Ca}$ & $\mathrm{P}$ \\
\hline$\%$ weight & $30.8073 \pm 0.0001$ & $14.8774 \pm 0.0001$ \\
$\begin{array}{l}\text { Atomic weight } \\
(\mathrm{g} / \mathrm{mol})\end{array}$ & 40.1 & 31.0 \\
$\begin{array}{l}\text { Sample molar content } \\
(100 \mathrm{~g})\end{array}$ & 0.77 & \\
$\mathrm{Ca} / \mathrm{P}$ ratio & & \\
\end{tabular}

Chemical analysis of precipitated HA by ICP OES resulted in a $1.60 \mathrm{Ca} / \mathrm{P}$ ratio, which is consistent with previous works ${ }^{11-13}$ that indicate that HA obtained by wet chemical routes is typically calcium deficient with a $\mathrm{Ca} / \mathrm{P}$ ratio between 1.5 and 1.67 .

The obtained biphasic powder has potential importance for biomedical applications combining the different behaviors of these materials when in contact with organic tissue. Specifically, the HA and $\beta$-TCP are major constituents of an extensively used biomedical material named Biphasic Calcium Phosphate (BCP). The IR analysis compared the calcined and uncalcined samples spectra (Figure 3). Bands at 1033-1038 and 1089-1094 $\mathrm{cm}^{-1} ;$ a medium intensity band around $962 \mathrm{~cm}^{-1}$; bands located at 565-567 and 601-603 $\mathrm{cm}^{-1}$; and a low-intensity band around $472-474 \mathrm{~cm}^{-1}$ are characteristic of phosphate group $\left(\mathrm{PO}_{4}^{3-}\right)$ of $\mathrm{HA}$.

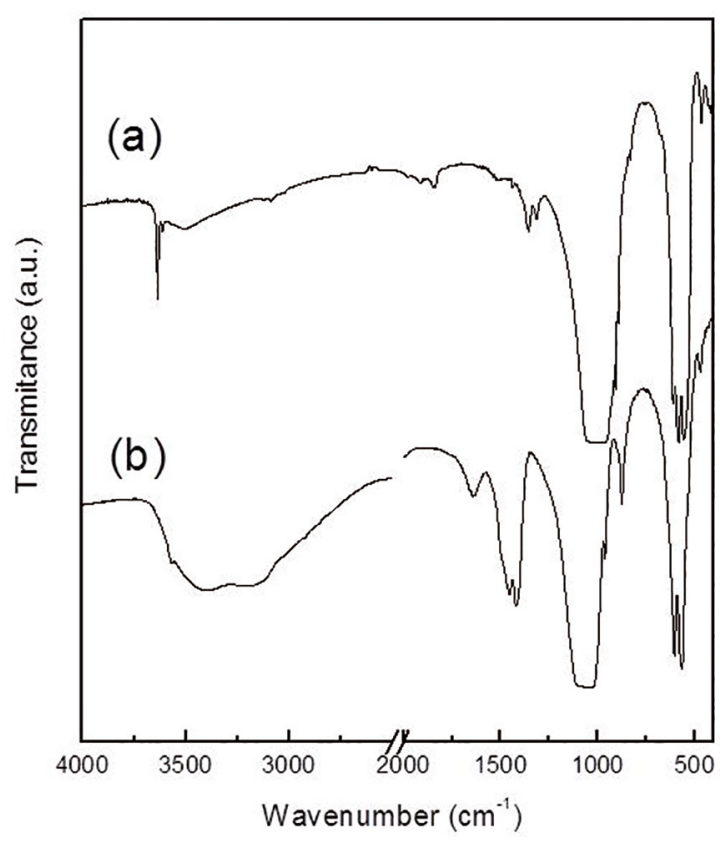

Figure 3: FTIR spectra of (a) calcined and (b) uncalcined samples.

Bands at 1650 and $3410 \mathrm{~cm}^{-1}$ indicate the presence of adsorbed water in surfaces of the HA particles. Bands at $877,1411-1421$ and $1453-1467 \mathrm{~cm}^{-1}$ were assigned as $\mathrm{CO}_{3}{ }^{2-}$, which is caused by an atmosphere-opened reaction that allows $\mathrm{H}_{2} \mathrm{O} / \mathrm{CO}_{2}$ incorporation in the particle's surface. 
After calcination, it is possible to observe a decrease in the intensity of these bands because adsorbed groups tend to be eliminated at high temperatures. Biological apatites are usually carbonated and slightly calcium deficient ${ }^{14}$. Consequently, the presence of these groups does not prejudice the use of this biphasic powder as a biomaterial.

After heating to $800^{\circ} \mathrm{C}$, there is a clear transformation of d-HA into stoichiometric HA and $\beta$-TCP. Analysis of the spectrum indicates bands of both compounds: the $\mathrm{OH}-$ characteristics bands at 3571-3576 and 630-633 $\mathrm{cm}^{-1}$ and the characteristic band of $\beta-\mathrm{TCP}$ at $944 \mathrm{~cm}^{-1}$. The $\mathrm{OH}^{-}$band at $630 \mathrm{~cm}^{-1}$ is a well known characteristic of $\mathrm{HA}$, a well defined triplet which shows the $\mathrm{PO}_{4}{ }^{3-}$ bonds at 601 and 570 $\mathrm{cm}^{-1}$ and the $-\mathrm{OH}$ bond to the apatite group at $630 \mathrm{~cm}^{-1}$.

SEM images with different approximations show round shaped grains and micrometric granulometry (Figure 4). Particles shape and size are directly influent in the inflammatory response and bone formation. They should not be needle-shaped form since it is not the propitious environment for bone cells development. Round particles with smooth surfaces are preferred ${ }^{15}$, because they induce a short-duration inflammatory response, followed by the desired incorporation of the biomaterial to the host tissue. On the other hand, needle-shaped particles cause granulomatous inflammation, accompanied by the material collapse and reabsorption by the surrounding tissues.

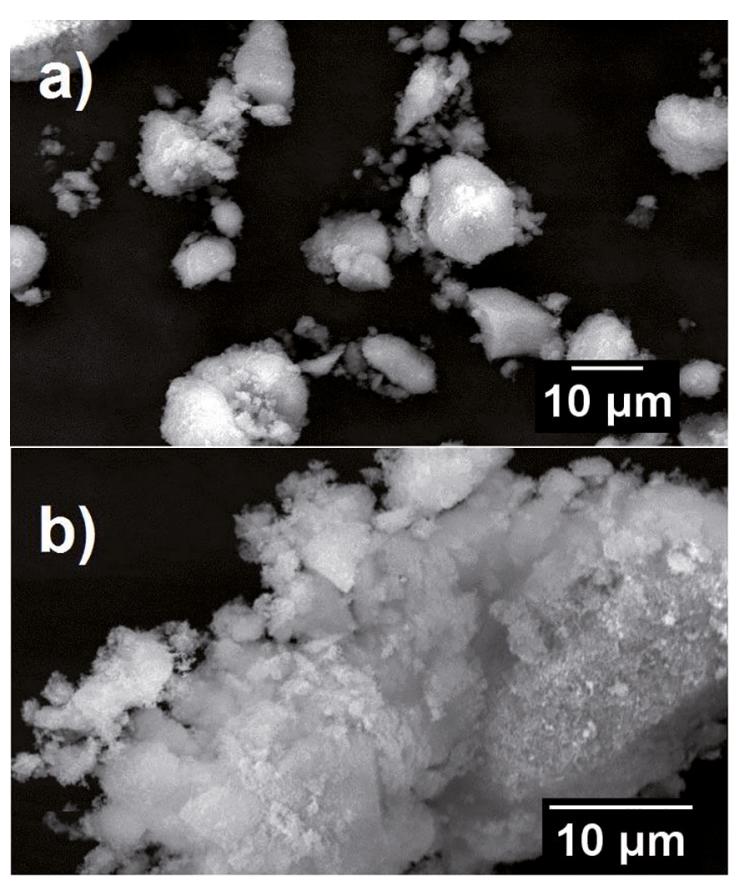

Figure 4: Image (a) show precipitated powders and (b) calcined powders.

Particle size was estimated by laser granulometry to vary from 0.1 to $100 \mu \mathrm{m}$ (Figure 5) and the calcined powder specific surface area is $11.70 \mathrm{~m}^{2} / \mathrm{g}$. Bioactive materials

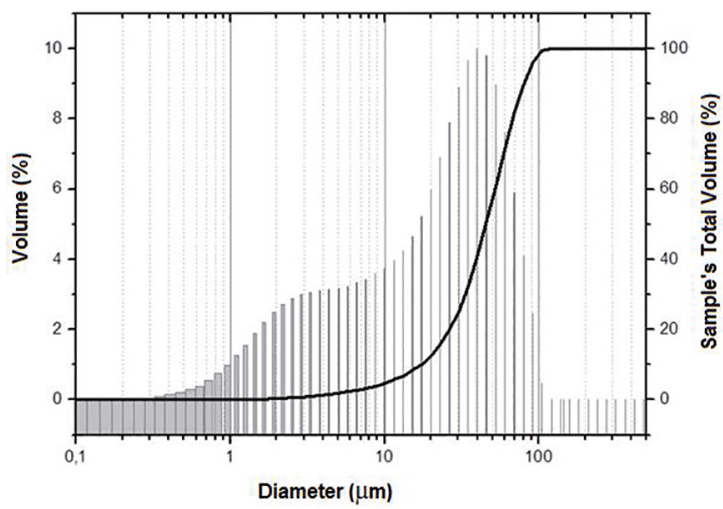

Figure 5: Biphasic powder particle size distribution.

such as HA, which act like substrate to bone tissue growth, are desirable to present the larger contact area possible facilitating the tissue growth. Produced BCP present a higher specific surface area than most of biomaterial for odontology implants tested by Conz ${ }^{16}$ as well as smallest particles size distribution, contributing to more surface to act as substrate.

The powder's combination of physical characteristics is biomedically valuable, since effective action of bioactive materials depends on a large contact area with the biological medium (bone tissue). Thus, powders with larger surface area should be better able to promote bone growth.

\section{Conclusions}

Ostrich eggshell is a low cost and abundant and pure source of calcium ions for the synthesis of biomaterials, producing a biomedically valuable biphasic powder of HA and $\beta$-TCP according to the desirable features a biomaterial should present listed by the literature. It was described a procedure that could be used to transform agricultural waste (ostrich eggshells) into an economically valuable high-quality new product, directly reducing discard and associated environmental impacts. Indeed, no other wastes were produced during HA synthesis.

\section{Acknowledgments}

The authors thanks CAPES, for the financial support; Santa Esmeralda Struthio Farm, for the ostrich eggshell supply for this work; LABPETRO-UFES, PMT-USP, DEMATCEFET-MG, LEEAA-USP for the characterization analysis.

\section{References}

1. Ribeiro C. Obtenção e caracterização de biocerâmicas porosas à base de fosfato de cálcio processadas com a utilização de albumina. [Tese de doutorado]. São Paulo: Instituto de Pesquisas Energéticas e Nucleares (IPEN); 2008. 
2. Petrov OE, Dyulgerova E, Petrov L, Popova R. Characterization of calcium phosphate phases obtained during the preparation of sintered biphase Ca-P ceramics. Materials Letters. 2001;48:(3-4):162-167.

3. Dupoirieux L. Ostrich eggshell as a bone substitute: a preliminary report of its biological behaviour in animals - a possibility in facial reconstructive surgery. British Journal of Oral and Maxillofacial Surgery. 1999;37(6):467-471.

4. Ahmed S, Ahsan M. Synthesis of Ca-hydroxyapatite Bioceramic from Egg Shell and its Characterization. Bangladesh Journal of Scientific and Industrial Research. 2008;43(4):501-512.

5. Suchanek W, Yoshimura M. Processing and properties of hydroxyapatite-based biomaterials for use as hard tissue replacement implants. Journal of Materials Research. 1998;13(1):94-117.

6. Dorozhkin SV. Calcium Orthophosphates in Nature, Biology and Medicine. Materials. 2009;2(2):399-498.

7. Khemthong P, Luadthong C, Nualpaeng W, Changsuwan P, Tongprem P, Viriya-empikul N, et al. Industrial eggshell wastes as the heterogeneous catalysts for microwave-assisted biodiesel production. Catalysis Today. 2012;190(1):112-116.

8. Chen G, Shan R, Shi J, Yan B. Ultrasonic-assisted production of biodiesel from transesterification of palm oil over ostrich eggshellderived CaO catalysts. Bioresource Technology. 2014;171:428-432.

9. Tan TH, Abdullah MO, Nolasco-Hipolito C, Taufiq-Yap YH. Waste ostrich- and chicken-eggshells as heterogeneous base catalyst for biodiesel production from used cooking oil: Catalyst characterization and biodiesel yield performance. Applied Energy. 2015;160:58-70.
10. Rivera EM, Araiza M, Brostow W, Castaño VM, Díaz-Estrada JR, Hernández R, et al. Synthesis of hydroxyapatite from eggshells. Materials Letters. 1999;41(3):128-134.

11. Mortier A, Lemaitre J, Rouxhet PG. Temperature-programmed characterization of synthetic calcium-deficient phosphate apatites. Thermochimica Acta. 1989;143:265-282.

12. Mostafa NY. Characterization, thermal stability and sintering of hydroxyapatite powders prepared by different routes. Materials Chemistry and Physics. 2005;94(2-3):333-341.

13. Raynaud S, Champion E, Bernache-Assollant D, Laval JP. Determination of Calcium/Phosphorus Atomic Ratio of Calcium Phosphate Apatites Using X-ray Diffractometry. Journal of the American Ceramic Society. 2001;84(2):359-366.

14. Vallet-Regí M, González-Calbet JM. Calcium phosphates as substitution of bone tissues. Progress in Solid State Chemistry. 2004;32(1-2):1-31.

15. Dalapicula SS, Vidigal Junior GM, Conz MB, Cardoso ES. Características físico-químicas dos biomateriais utilizados em enxertias ósseas. Uma revisão crítica. ImplantNews. 2006;3(5):487-491.

16. Conz MB, Campos CN, Serrão SD, Soares GA, Vidigal Junior GM. Caracterização físico-química de 12 biomateriais utilizados como enxertos ósseos na Implantodontia. ImplantNews. 2010;7(4):541-546. 